\title{
TRANSNATIONAL NEEDS OF SUSTAINABLE SPATIAL DEVELOPMENT IN THE ALPS: RESULTS FROM AN ANALYSIS OF POLICY DOCUMENTS
}

Stefan Marzelli, Florian Lintzmeyer

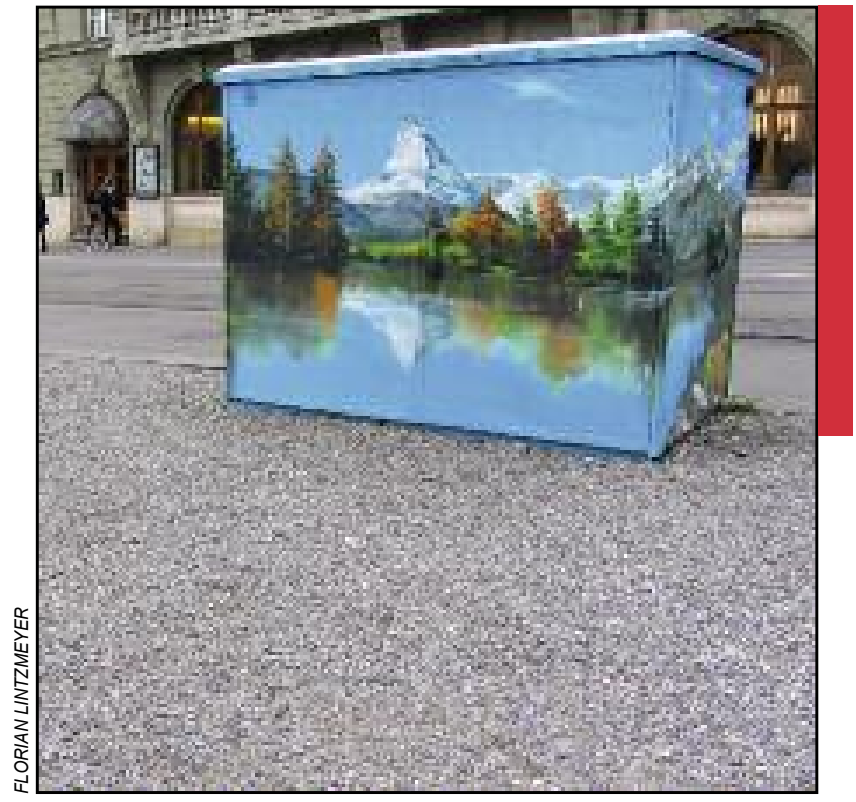

Nature protection and economic competitiveness: what are policy fields of transnational spatial development in the Alps? 


\section{Transnational needs of sustainable spatial development in the Alps: results from an analysis of policy documents}

DOI: http://dx.doi.org/10.3986/AGS.1585

UDC: $913: 711(234.3)$

711:502.131(234.3)

COBISS: 1.01

ABSTRACT: Spatial planning documents referring to the Alps address the needs of transnational spatial development. This article presents selected results from an analysis of thirty-two spatial planning strategies, plans, and reports carried out within the European Transnational Cooperation and Alpine Space Programme's WIKIAlps project (2007-2013). The results include a quantitative analysis of the dimension of transnational needs, added value, and obstacles as perceived in these framework documents on spatial development. The documents were also analyzed with regard to references to stakeholder groups relevant for addressing these transnational needs. The analysis emphasizes that more transnational coordination is desirable in many policy fields, from strategy development and governance processes, to more coordinated management of natural resources, to building an appropriate knowledge base for transnational decision-making.

KEY WORDS: geography, spatial development, spatial planning, document analysis, transnational needs, obstacles, added value, stakeholders, Alps

The article was submitted for publication on November $11^{\text {th }}, 2014$.

\section{ADDRESSES:}

\section{Stefan Marzelli}

Institute for Environmental Planning and Spatial Development - IFUPLAN

Amalienstr. 79, DE - 80799 Munich, Germany

E-mail: stefan.marzelli@ifuplan.de

\section{Florian Lintzmeyer}

Institute for Environmental Planning and Spatial Development - IFUPLAN

Amalienstr. 79, DE - 80799 Munich, Germany

E-mail: florian.lintzmeyer@ifuplan.de 


\section{Introduction}

The main focus of the WIKIAlps project was to identify and categorize contributions of the Alpine Space Programme's projects to sustainable transnational development in the Alps. One preliminary working step in this regard is to investigate which transnational implications are found in regional, national, and international spatial development documents, strategies, and plans. The underlying assumption is that these documents address issues of particular relevance for Alpine spatial development at the national and regional levels (cf. Price et al. 2011, Dühr 2013 and Haßlacher 2007). Spatial development per se is nonspecific and requires a normative framework with regard to its policy objectives. Spatial development as understood in the WIKIAlps project therefore includes sustainability criteria for spatial development as outlined by the European Conference of Ministers responsible for spatial planning (CEMAT 2000) and the Alpine Convention Implementation Protocol on Spatial Planning and Sustainable Development (Protocol ... 1994).

References with regard to transnational needs are therefore a valuable indication of which issues require a stronger transnational approach in order to steer Alpine development towards sustainability. This article presents the results of a document analysis and discusses the relation between issues deemed of transnational importance and the factual governance framework for coordinated spatial development in the Alps.

\section{Objective and method}

The objective of the document analysis was to screen the most relevant national and regional spatial planning documents of the Alpine countries as well as selected transnational documents of spatial relevance with regard to their references to transnational needs of spatial development. The assumption is that this document analysis will produce a consolidated framework of required and complementary steps necessary to promote sustainable spatial development at a transnational level to which individual projects can contribute.

The analysis was carried out by the WIKIAlps project partnership between January and April 2014. Thirty-one documents were analyzed (cf. Figure 1) covering different spatial entities. Twenty-one documents focused on national or regional spatial development within one country. Six specifically addressed cross-border regions between two countries, and the remaining four addressed spatial development in more than two countries.

Among the twenty-one national or regional documents were six documents from France, two documents from Switzerland, two documents from Germany, seven documents from Italy, and four documents from Slovenia.

The analytical framework for each document comprised the following questions:

a) What is the transnational dimension of each specific topic, and why is it relevant at a transnational scale?

b) What added value is expected from transnational spatial development?

c) What obstacles currently impede transnational spatial development approaches?

d) What proposals are being made with regard to the issue?

e) What key stakeholders for the topic are mentioned?

f) Which good examples / pilot activities does the document refer to with regard to the abovementioned topic?

g) Personal comment by the analyst.

This article focuses on a quantitative analysis of the specific dimension of transnational needs, the added value expected from transnational spatial development, the obstacles that currently impede transnational approaches and stakeholders that are deemed relevant for appropriately addressing these issues.

\subsection{Quantitative analysis}

The analysis of spatial development documents (Analysis ... 2014) produced a total of 182 different transnational needs. Most of these individual needs contain a detailed description of the transnational dimension, the added value that can be expected from respective improvements, the current obstacles that currently impede spatial development, and relevant stakeholders required for transnational spatial development. 
Stefan Marzelli, Florian Lintzmeyer, Transnational needs of sustainable spatial development in the Alps ...

Table 1: Analyzed documents.

\section{TRANSNATIONAL}

- European Commission 1999: ESDP European spatial development perspective, Towards balanced and sustainable development of the territory of the European Union. Brussels.

- European Union 2013: ULYSSES - Using applied research results from ESPON as a yardstick for cross-border spatial development planning. Luxembourg.

- Joint technical secretariat of the Alpine space programme 2013: Strategy development for the Alpine space. Munich.

- Permanent secretariat of the Alpine convention 2011: Sustainable rural development and innovation. Innsbruck.

\section{BINATIONAL}

- Regione autonoma Friuli-Venezia-Giulia, Regione del Veneto, Provincia autonoma di Bolzano, Land Kärnten, Land Salzburg, Land Tirol 2007: Operationelles Programm zur Förderung der grenzüberschreitenden Zusammenarbeit im Grenzraum zwischen Österreich - Italien.

- Grand Genève agglomération franco-valdo-genevoise 2012: Charte 2012 du projet d'agglomération franco-valdo-genevois. Geneva.

- Regione Lombardia, Regione Piemonte, Regione autonoma Valle d'Aosta, Provincia autonoma di Bolzano, Kanton Graubünden, Cantone Ticino, Canton du Valais 2007: Obiettivo »Cooperazione territorial Europea«, Programma per la cooperazione transfrontaliera Italia Svizzera 2007-2013.

- ALCOTRA (ed.) 2007: Programma di cooperazione transfrontaliera Italia Francia.

- IPA Adriatic CBC (ed.) 2007: IPA Adriatic cross-border cooperation programme.

- Regione autonoma Friuli-Venezia-Giulia, Regione del Veneto, Regione Emilia-Romagna, Republika Slovenija 2007: Programma per la cooperazione transfrontaliera Italia-Slovenia 2007-2013.

\section{GERMANY}

- Bundesinstitut für Bau-, Stadt- und Raumforschung 2012: Raumordnungsbericht 2011. Bonn.

- Bayerische Staatsregierung 2013: Landesentwicklungsprogramm Bayern (LEP). Munich.

\section{FRANCE}

- Comité du Massif des Alpes 2013: Schema interregional du massif des Alpes. Grenoble.

- Conseil Régional de la région Rhône-Alpes 2013: Schéma régional de cohérence ecologique Rhône-Alpes. Lyon.

- Direction régionale de l'environnement, de l'aménagement et du logement Rhône-Alpes (DREAL Rhône-Alpes) 2010: Directive territoriale d'aménagement des Alpes du Nord. Lyon.

- Prefecture des Alpes-Maritimes 2003: La directive territoriale d'aménagement des Alpes-Maritimes. Nice.

- Loi no 85-30 du 9 janvier 1985 relative au développement et à la protection de la montagne. Journal officiel de la République Française, 10.1. 1985.

- COPIL SDD, CEDDAET, Groupement Thomasset, Groupement SDD - Mont-Blanc Valais 2005. Schéma de developpement durable de l'espace Mont Blanc.

\section{ITALY}

- Autonome Provinz Bozen - Südtirol 1995: Südtirol - Leitbild 2000, Landesentwicklungs- und Raumordnungsplan (LEROP). Bozen.

- Ministero dell'Ambiente e della tutela del territorio e del mare 2013: Elementi per una Strategia nazionale di adattamento ai cambiamenti climatici, Documento per la consultazione pubblica. Roma.

- Ministero delle politiche agricole alimentare e forestale 2010: Piano strategico nazionale per lo sviluppo rurale 2007-2013. Roma.

- Regione Autonoma Friuli Venezia Giulia 2013: Piano del Governo del Territorio. Trieste.

- Regione del Veneto - giunta regionale 2013: Programma di sviluppo rurale per il Veneto 2007-2013. Venezia.

- Ministero sviluppo economico 2013: Strategia energetica nazionale, per un'energia più competitiva e sostenibile. Roma.

- Regione Piemonte 2011: Piano territoriale regionale. Torino.

\section{SWITZERLAND}

- Schweizerischer Bundesrat 2012: Strategie Nachhaltige Entwicklung 2012-2015. Bern.

- Schweizerischer Bundesrat, KdK, BPUK, SSV, SGV 2012: Raumkonzept Schweiz. Bern.

\section{SLOVENIA}

- Government office for local self-government and regional policy 2011: 0perational programme for strengthening regional development potentials for the period 2007-2013. Ljubljana.

- Institute of macroeconomic analysis and development 2005: Slovenia's development strategy. Ljubljana.

- Ministry of the environment and spatial planning 2004: Resolution on national environmental action plan 2005-2012. Ljubljana.

- Ministry of the environment, spatial planning and energy 2004: Spatial development strategy of Slovenia. Ljubljana. 
To be able to carry out a quantitative analysis of this data collection, the following steps were carried out: first each of the 182 individual entries was indexed with an individual keyword, and then related keywords were summarized into a keyword category. The quantitative analysis is based on these keyword categories. The process is described in Table 1.

Table 2: From text reference to keyword category (example).

\begin{tabular}{lll}
$\begin{array}{l}\text { Original text reference in the spatial planning document; } \\
\text { for example, regarding the transnational dimension }\end{array}$ & Individual keyword & Keyword category \\
\hline $\begin{array}{l}\text { Community strategic guidelines for rural development } \\
\text { (programming period } 2007 \text { to } 2013)(2006 / 144 / E C):\end{array}$ & $\begin{array}{l}\text { Rural areas' endogenous } \\
\text { development potential }\end{array}$ & Rural development \\
simproving governance and mobilizing the endogenous & & \\
development potential of rural areas«
\end{tabular}

Individual keywords summarized in the keyword category »rural development « include »employment opportunities in rural areas, « »marginalization of rural areas, « »improving the attractiveness of rural areas, " »rural areas' endogenous development potential, « and »rural development. « As a methodological shortcoming, it needs to be mentioned that, due to the thematic complexity of spatial development and the unavoidable overlap between categories (e.g., between »Cooperation and networking " and »Economic cooperation and exchange "), the allocation of individual keywords to one category or another required weighing different arguments. In some cases and despite an internal review of each allocation, the categorization can be justifiably debated (WIKIAlps Consortium 2014).

Not all four categories (dimension, added value, obstacles, and relevant stakeholders) could be filled for every transnational need; in several cases, one or two of these categories contained no or no applicable entry. Consequently, there are differing numbers of entries for these three categories.

Inevitably, this categorization step results in the loss of specific aspects, which would require in-depth analysis of each transnational need. On the other hand, it is necessary to arrive at an understandable overview, which is one of the key objectives of the WIKIAlps project.

\section{Results}

With 182 references to transnational needs, each document analyzed contains six references on average. At first glance, this appears to be surprisingly few. One explanation might be that, historically and institutionally, most of the documents were drafted and adopted by institutions such as ministries or agencies that strongly or almost exclusively focus on their own areas of competence, in both the territorial and sectoral sense.

\subsection{Transnational dimension of topics}

Not surprisingly, most of the dominant categories of transnational needs are rather nonspecific categories, such as cross-border development and territorial cohesion, spatial planning and development, policy and governance, and cooperation and networking (cf. Table 2). On the other hand, some specific policy fields also emerge such as the issue of connectivity and accessibility, which subsume corridors, accessibility of isolated areas, transport, and logistics. Additional specific topics of transnational relevance are water management, biodiversity, economic cooperation, and exchange.

At the other end of the scale, it is surprising to note that issues such as climate change, ecosystem management, and demographic change - issues that have been dominating recent national debates in spatial development - are perceived to have a limited transnational dimension according to the documents.

\subsection{Added value of transnational spatial development}

In almost half of the cases, the spatial planning documents refer to transnational needs, but do not outline which added value can be expected from a more transnational approach to these issues (cf. Table 3). 
The most frequent added value is seen in the management of natural resources and ecosystems, a coherent strategy development and implementation, and transport and accessibility. Added value is also seen in an economic sense (competitiveness, knowledge sharing, and transfer) and in energy and natural-risk management. Added value with regard to European Union (EU) policies is seen with regard to achieving EU policy objectives on the one hand, but also with regard to improving access to EU funds through transnational cooperation.

\subsection{Obstacles impeding transnational spatial development}

The most relevant obstacles identified are administrative, legal, and cultural differences and lack of cross-border coordination, data, and knowledge (cf. Table 4). Given the fragmentation of the Alps by administrative and cultural borders, the first obstacle hardly comes as a surprise. It comprises the regulatory and administrative framework, but also the difficult task of coordinating policies and instruments both vertically and horizontally in the Alps across borders. The second most relevant obstacle goes to the core of what capitalization projects such as WIKIAlps are trying to achieve: to improve the knowledge base for sound decision-making with regard to policy fields of a transnational dimension and thus contribute to cross-border coordination.

Table 3: Transnational dimension of topics $(n=182)$.

\begin{tabular}{|c|c|}
\hline The topic has a transnational dimension in: & Count \\
\hline - Cross-border development and territorial cohesion in general & 33 \\
\hline - Connectivity and accessibility & 14 \\
\hline - Spatial planning and development & 12 \\
\hline $\begin{array}{l}\text { - Policy and governance } \\
\text { - Cooperation and networking }\end{array}$ & 11 each \\
\hline $\begin{array}{l}\text { - No reference } \\
\text { - Water management }\end{array}$ & 9 each \\
\hline - Biodiversity & 8 \\
\hline - Economic cooperation and exchange & 7 \\
\hline $\begin{array}{l}\text { - Rural development } \\
\text { - Energy }\end{array}$ & 6 each \\
\hline $\begin{array}{l}\text { - Settlement development } \\
\text { - Urban-rural relationship } \\
\text { - Tourism } \\
\end{array}$ & 5 each \\
\hline $\begin{array}{l}\text { - Research, development, and capacity building } \\
\text { - Natural resource management } \\
\text { - Agriculture/forestry } \\
\text { - Cultural heritage and identity } \\
\text { - Natural hazards }\end{array}$ & 4 each \\
\hline $\begin{array}{l}\text { - Coordination with European policies } \\
\text { - Not applicable }\end{array}$ & 3 each \\
\hline $\begin{array}{l}\text { - Protected areas } \\
\text { - Climate change } \\
\text { - Ecosystem management } \\
\text { - Information and communication technologies } \\
\text { - Relations between cities }\end{array}$ & 2 each \\
\hline $\begin{array}{l}\text { - Foods } \\
\text { - Demographic change } \\
\text { - Funding } \\
\text { - Statistical data } \\
\text { - Air pollution }\end{array}$ & 1 each \\
\hline
\end{tabular}


The perception that spatial development is competitive rather than cooperative is a manifestation of a recent paradigm shift in spatial planning policies. Once mainly focusing on balancing polarized spatial development processes (e.g., between thriving agglomerations and peripheral areas) and providing a solid framework against pressures on natural resources (e.g., the zoning of the Bavarian Alps in the Bavarian Spatial Development Program), spatial planning itself is increasingly seen as promoter of economic development. This ambivalence is reflected in the perception that competition impedes transnational spatial development, while at the same time increased competitiveness is seen as a potential added value of such development.

The lack of accessibility comprises various transport modes and purposes, from obstacles such as lacking competitiveness of combined transport to lacking urban-rural public transportation links and poor transnational connections.

A cross-cutting issue throughout several categories is the perception that Alpine stakeholders lack a common understanding of transnational spatial development, partly due to the inherent conflict of interest of stakeholders from the local to the national levels. On the one hand, stakeholders and decision-makers are above all accountable for their respective territory and topics; on the other hand, it is increasingly obvious that policy fields can no longer be appropriately steered within these confined territories.

\subsection{Relevant stakeholders}

Which institutions and stakeholders need to be addressed in the context of the transnational needs outlined in the documents analyzed? In the case of ninety-eight of the total of 182 transnational needs, the documents

Table 4: Added value of transnational spatial development $(n=182)$.

\begin{tabular}{|c|c|}
\hline Potential added value is seen in: & Count \\
\hline - No reference & 70 \\
\hline $\begin{array}{l}\text { - Management of natural resources and ecosystems } \\
\text { - Strategy development and implementation } \\
\text { - Transport and accessibility }\end{array}$ & 11 each \\
\hline - Competitiveness & 9 \\
\hline - Energy & 7 \\
\hline $\begin{array}{l}\text { - Natural risk management } \\
\text { - EU policies } \\
\text { - Knowledge sharing and transfer } \\
\end{array}$ & 6 each \\
\hline $\begin{array}{l}\text { - Ecological networks } \\
\text { - Coordinated settlement development }\end{array}$ & 5 each \\
\hline $\begin{array}{l}\text { - Tourism } \\
\text { - Spatial planning } \\
\text { - Urban-rural development / functional areas / urban and regional networks }\end{array}$ & 4 each \\
\hline $\begin{array}{l}\text { - Rural development } \\
\text { - Qualification and access to labor force } \\
\text { - Border regions }\end{array}$ & 3 each \\
\hline $\begin{array}{l}\text { - Participation } \\
\text { - Biodiversity } \\
\text { - Social and health systems } \\
\text { - ICT } \\
\text { - Public services }\end{array}$ & 2 each \\
\hline $\begin{array}{l}\text { - Agricultural products } \\
\text { - Education } \\
\text { - Cooperation } \\
\text { - Cooperation and coordination }\end{array}$ & 1 each \\
\hline
\end{tabular}


Stefan Marzelli, Florian Lintzmeyer, Transnational needs of sustainable spatial development in the Alps ...

refer to relevant stakeholders that can contribute to more coordinated spatial development in the specific regard. Given the complexity of needs, it is not surprising that, for many transnational needs, the documents refer not to one single stakeholder, but a multitude of stakeholders, resulting in a total number of 391 references to individual stakeholders (Table 5).

Table 5: Obstacles impeding transnational spatial development $(n=182)$.

\begin{tabular}{lc}
\hline Obstacles are seen in: & Count \\
\hline - No reference & 118 \\
\hline - Administrative, legal, and cultural differences & 10 each \\
- Lack of cross-border coordination, data, and knowledge & 7 each \\
\hline - Not applicable & 4 each \\
- Lack of accessibility & 3 each \\
- Competition instead of cooperation & \\
- Lacking awareness of cultural and natural heritage & \\
- Different interests & 2 each \\
- Spatial disparities & \\
- Artificial barriers & \\
- Sectoral policies & \\
- Implementaltion deficits & 1 each \\
- Economic structures \\
- Lack of transnational institutional setup \\
- Management capacities \\
- Lack of policy framework \\
\hline
\end{tabular}

Table 6: References to relevant stakeholder categories with regard to transnational needs.

\begin{tabular}{lc}
\hline Stakeholder category & Count \\
\hline Public bodies (at various administrative levels, excluding municipalities) & 56 \\
Ministries (as a subcategory of public bodies) & 37 \\
NGO/NPO (nongovernmental/nonprofit organizations) & 33 \\
Spatial planning authorities (and other spatial planning stakeholders) & 27 \\
Public agencies & 25 \\
Networks & 24 \\
Towns/municipalities & 21 \\
Private sector & 19 \\
University/institutes of applied science & 19 \\
Research institute/center & 17 \\
Protected area management bodies & 16 \\
Development agencies & 16 \\
Intermunicipal associations & 14 \\
Chambers of trade and crafts & 13 \\
Clusters (R\&D) & 13 \\
Chambers of commerce and industry & 12 \\
Citizens & 9 \\
Providers of public services & 8 \\
Other & 5 \\
Planning consultancies & 5 \\
Technological and research centers & 2 \\
\hline Total & 391 \\
\hline
\end{tabular}


Again, individual entries were categorized into twenty-one categories covering public and governmental institutions and levels, the private sector with its representations, education and research institutions, and civil society:

- Public and governmental institutions account for a total of 220 references; these include public bodies, ministries, spatial planning organizations, public agencies, towns/municipalities, protected area management bodies, development agencies, intermunicipal associations, and providers of public services;

- Civil society accounts for a total of sixty-six references; these include NGO/NPO, networks and, the general public;

- The private sector and its representations account for a total of sixty-two references; these include the private sector, chambers of trade and crafts, chambers of commerce and industry, clusters (R\&D), and planning consultancies;

- Education and research institutions account for a total of thirty-eight references; these include universities/institutes of applied sciences, research institutes/centers, and technological and research centers.

In certain cases, the classification of these categories is not unambiguous. Providers of public services, for instance, comprise providers of services of general interest and public companies (usually at least partly state-owned or regulated) and fully public companies. Despite being classified as a public institution, this category also belongs to the private sector to a certain extent.

Thus, although governmental institutions remain the core stakeholder group for furthering spatial challenges of transnational relevance, it is also obvious that stakeholders outside the governmental arena (foremost civil society and the private sector, but also universities and research institutions) are seen as vital and essential partners.

\section{Discussion}

Provocatively, it can be argued that there is a widening gap between the increasing urgency for coordinated spatial development and planning, and there is a loss of relevance of spatial planning institutions and documents throughout Europe. In the 1990s, the Alpine Convention process resulted in the adoption of an entire protocol dedicated to spatial planning and sustainable development. At the European level, the European Spatial Development Perspective of 1999 (European Commission 1999) outlined issues and fields of action for European spatial planning initiatives that transcend national borders to appropriately tackle issues that can no longer be solved within individual countries. Subsequently, however, the transnational planning enthusiasm was replaced by the current funding- and project-based approach to European cohesion policy (Kunzmann 2014).

The same marginalization of a formal planning framework can also be observed at a national level. For instance, in Germany, the former National Framework on Spatial Planning Policy (Raumordnungspolitischer Orientierungsrahmen 1993) was replaced in 2006 by Concepts and Strategies for Spatial Development in Germany (cf. Federal Ministry 2006). In a sematic sense, spatial planning seems to no longer provide a framework for decision-making processes, but an orientation instead.

Looking at the Alps, borders and national differences do not pose a problem per se. In fact, cultural differences and also different policy approaches to issues are instead what make the Alps such a unique place in the middle of Europe. In the transport sector, the exemplary Swiss approach to promoting public transportation and limiting freight transport volumes on the road, for example, might not have been feasible in comparable time if it were adopted by all Alpine countries - especially bearing in mind that mountain-oriented policies are marginal in the national political agenda of large area Alpine countries such as Italy, France, or Germany.

However - and the analysis outlined emphasizes this point - there are spatial development issues of an undisputable transnational dimension that require stronger transnational cooperation and coordination (cf. Federal Ministry of Transport, Building and Urban Affairs et al. 2009). At an abstract level, few would oppose this. Many topics of a transnational dimension, however, require substantial modifications with regard to the institutional and administrative framework as well as regarding the agendas of stakeholders and decision-makers in the Alps and beyond. The wide range of stakeholders considered essential for achieving progress with regard to transnational spatial needs illustrates not only the complexity, but also the huge momentum, that can be drawn from stronger coordination across borders. 
Awareness of the need for closer transnational coordination in Alpine policy and governance therefore needs to be strengthened among national institutions. In the long run, this might even imply the transfer of responsibilities and legitimacy from national institutions to binational or multinational institutions in the Alps, depending on the extent of transnational coordination. The need for coordinating sector policies at a supranational level in ecosystem management, tourism, or commercial development is a specifically Alpine issue (cf. Price et al. 2011), considering the relevance of Alpine ecological functions inside the Alps and also for neighboring lowlands, tourism for certain Alpine areas, and the considerable short-term benefits that regions can draw from deregulating urban development zoning laws at the expense of their cross-border neighboring regions.

In an environment of governance-oriented spatial planning policies, this could include defining minimum standards as well as appropriate cartographic definitions for undesirable processes and spatial outcomes. The State Development Program of Bavaria, for instance, differentiates the German topographic Alpine area into three zones (Erholungslandschaft Alpen or Alpenplan, cf. Bayerische Staatsregierung 2013) with different implications for tourism projects. Forty years after its introduction, it can be stated that this instrument proved relatively successful in containing the negative spatial outcomes of tourism and commercial development. However, the question remains how to balance spatial development in the Alps between these stringent analytical needs and their spatial delineations on the one hand, and bottom-up processes and local agendas on the other. In any case, the different economic and ecosystematic functions of individual regions need to be accompanied by the establishment of substantial regional and even transnational compensation mechanisms (e.g. the Greina Foundation and regional pools of commercial areas), thus creating effective incentives for spatially adapted development models in the Alps.

With the analysis of current spatial planning documents with relevance for the Alps, the WIKIAlps project provides an overview of the existing strategic framework for spatial planning and development in the Alps. The topics identified could serve as a starting point for Alpine policies (e.g., the Alpine Convention, Alpine Space Programme, and EUSALP process) to promote transnational approaches in relevant policy fields.

\section{References}

Analysis of national documents in regard to needs and challenges of transnational spatial development. 2014. Institut für Umweltplanung und Raumentwicklung. Munich. Internet: http://www.wikialps-project.eu/working-material/Documents/action_4_2_working_paper_transnational_needs.pdf (22.1.2015).

Bayerische Staatsregierung 2013: Landesentwicklungsprogramm Bayern (LEP). Munich. Internet: http://www.landesentwicklung-bayern.de/fileadmin/user_upload/landesentwicklung/Bilder/Instrumente/ Landesentwicklungsprogramm_Bayern.pdf (14.11.2014).

Federal ministry of transport, building and urban affairs (BMVBS), Federal office for building and regional planning (BBR) 2009: Impacts and benefits of transnational projects (INTERREG III B). Berlin. Internet: http://www.bbsr.bund.de/BBSR/EN/Publications/BMVBS/Forschungen/2009/DL_138.pdf;jsession$\mathrm{id}=$ B059856663283BC95D4642F5BA3A7B05.live2052?_blob=publicationFile\&v=2 (18.11.2014).

CEMAT - European conference of ministers responsible for regional planning 2000: Guiding principles for sustainable spatial development of the European continent. Internet: http://www.coe.int/t/dgap/ localdemocracy/cemat/VersionPrincipes/Anglais.pdf (7.11.2014).

Dühr, S., Nadin, V., Colomb, C. 2010: European spatial planning and territorial cooperation. London. DOI: http://dx.doi.org/10.4324/9780203895290

European Commission 1999: ESDP European spatial development perspective, towards balanced and sustainable development of the territory of the European Union. Brussels. Internet: http://ec.europa.eu/ regional_policy/sources/docoffic/official/reports/pdf/sum_en.pdf (14.11.2014).

Federal ministry of transport, building and urban affairs (BMVBS) (Ed.) 2006: Concepts and strategies for spatial development in Germany. Berlin.

Haßlacher, P. 2007: Alpine Raumordnung. Ländlicher Raum Jahrgang 2007. Wien. Internet: http://www.bmlfuw.gv.at/ dms/lmat/land/laendl_entwicklung/Online-Fachzeitschrift-Laendlicher-Raum/archiv/2007/Hasslacher/ Ha_lacher_pdf_END.pdf (14.11.2014). 
Kunzmann, K. 2014: Kohäsion und Raumordnung. Nachrichten, Magazin der Akademie für Raumforschung und Landesplanung 3.

Price, M., Borowski, D. Macleod, C. Rudaz, G. Debarbieux, B. 2011: Sustainable mountain development in the Alps, from Rio 1992 to Rio 2012 and beyond. Perth/Geneva. Internet: http://www.mountainpartnership.org/fileadmin/user_upload/mountain_partnership/docs/ALPS\%20FINAL\%2020120228\%20 RIO\%20Alps.pdf (14.11.2014).

Protocol on the implementation of the Alpine convention of 1991 relating to spatial planning and sustainable development, 1994. Internet: http://www.alpconv.org/en/convention/protocols/Documents/Protokoll_ RaumplanungGB.pdf (11.9.2014).

Raumordnungspolitischer Orientierungsrahmen: Leitbild für die räumliche Entwicklung der Bundesrepublik Deutschland. 1993. Bundesministerium für Raumordnung, Bauwesen und Städtebau. Internet: https://www.umweltbundesamt.de/sites/default/files/medien/377/dokumente/raumordnungspolitischer_ orientierungsrahmen.pdf (22.1.2015).

WIKIAlps Consortium 2014: WIKIAlps synthesis booklet. Bolzano. Internet: http://www.wikialps-project.eu/ working-material/Documents/WIKIALPS_booklet.pdf (22.1.2015). 
